\title{
PEMANFAATAN QGIS UNTUK PEMETAAN FASILITAS LAYANAN MASYARAKAT DI KOTA PONTIANAK
}

\author{
Syamsul Bahri ${ }^{1}$, Dwi Marisa Midyanti ${ }^{2}$, Rahmi Hidayati ${ }^{3}$
}

${ }_{1,2,3}$ Rekayasa Sistem Komputer Universitas Tanjunpura

1,2,3 Jalan Prof. Dr. H. Hadari Nawawi Pontianak, 78124 Indonesia

${ }^{1}$ syamsul.bahri@siskom.untan.ac.id, ${ }^{2}$ dwi.marisa@siskom.untan.ac.id, ${ }^{3}$ rahmihidayati@siskom.untan.ac.id,

\begin{abstract}
Abstrak- Kota Pontianak merupakan ibukota Provinsi Kalimantan Barat yang memiliki 6 kecamatan dengan total luas wilayah $107,82 \mathrm{~km}^{2}$. Hingga tahun 2018 jumlah penduduk kota Pontianak mencapai 665.694 jiwa. Kepadatan penduduk tiap kecamatan di Kota Pontianak relatif tidak merata, yang mengakibatkan sebaran fasilitas pelayanan publik menjadi tidak merata. Seringkali masyarakat di beberapa kecamatan kesulitan menemukan fasilitas pelayanan publik yang terdekat. Fasilitas pelayanan publik yang digunakan oleh masyarakat, diantaranya seperti ATM, SPBU, Puskesmas, Rumah Sakit, PAUD, dan Bengkel. Solusi yang dapat dilakukan untuk permasalahan tersebut salah satunya adalah memanfaatkan aplikasi QGIS untuk pemetaan fasilitas layanan masyarakat. Penelitian ini menghasilkan sebuah peta web yang memetakan fasilitas layanan yang ada di kota Pontianak. Peta web ini diharapkan dapat bermanfaat dan mempermudah masyarakat menemukan lokasi fasilitas layanan publik yang ada di Kota Pontianak.
\end{abstract}

Kata Kunci-SIG, QGIS, pemetaan, fasilitas publik, layanan masyarakat, pontianak

Abstract- The City of Pontianak is the capital of West Kalimantan Province which is divided into 6 districts covering a total area of $107.82 \mathrm{~km}^{2}$. The city has been inhabited by 665,694 inhabitants until 2018. The population density of each district in Pontianak is relatively uneven, which causes the uneven distribution of public service facilities throughout the city. The people in several districts frequently have some problems to find the nearest public service facility. The public service facilities which are used by the public community include the ATMs, gas stations, health care centers or health clinics, hospitals, early-childhood education centers, and automotive workshops. One of the solutions that can be implemented to overcome the problem is to utilize the QGIS application for mapping the location of the existing public service facilities. This research produces and creates a web map that can trace the public service facilities in the city of Pontianak. This web map is expected to be beneficial and make it easier for the people in finding the location of public service facilities in the city of Pontianak.

Keywords - SIG, QGIS, mapping, public service facilities, community services, Pontianak

\section{PENDAHULUAN}

Kota Pontianak merupakan ibu kota Provinsi Kalimantan Barat yang memiliki 6 kecamatan dengan total luas wilayah 107,82 kilometer persegi. Hingga semester II tahun 2018 jumlah penduduk kota Pontianak sudah mencapai 665.694 jiwa. Jumlah tersebut sudah mengalami pertambahan sebesar 1.300 jiwa jika dibandingkan jumlah penduduk semester I tahun 2018 yang berjumlah 664.394 jiwa [1].

Sebaran penduduk di kota Pontianak terbilang belum merata, terlebih akibat faktor geografis wilayah di kota Pontianak yang terbagi atas beberapa bagian yang dipisahkan sungai. Kepadatan penduduk setiap kecamatan di Kota Pontianak relatif tidak merata, hal ini mengakibatkan sebaran fasilitas pelayanan publik juga relatif tidak merata. Beberapa fasilitas pelayanan publik mayoritas terletak di pusat Kota Pontianak. Mulai dari bidang ekonomi, kesehatan hingga pendidikan merupakan fasilitas pelayanan publik yang setiap hari selalu digunakan oleh masyarakat, diantaranya seperti ATM, SPBU, Puskesmas, PAUD, dan lain sebagainya.

Oleh karena sebaran fasilitas pelayanan publik yang relatif tidak merata, seringkali masyarakat di beberapa kecamatan kesulitan menemukan fasilitas pelayanan publik yang terdekat. Sementara untuk mengakses fasilitas yang terdapat di pusat kota memiliki hambatan aksesibilitas, khususnya jarak dan waktu tempuh.

Solusi yang dapat dilakukan atas permasalahan tersebut salah satunya adalah dengan melakukan pemetaan lokasi fasilitas layanan publik tersebut dalam sebuah sistem informasi geografis (SIG) yang dapat diakses oleh masyarakat luas.

Sistem informasi geografis seperti ini juga pernah dibangun oleh Abdulghani dan Ubaedilah [2] yang melakukan perancangan SIG sebaran tanah penduduk di desa Tanjungsara Kabupaten Cianjur. Keuntungan dibangunnya sistem ini adalah kemudahan bagi petugas kantor kepala desa dalam menambah, memperbaharui dan mencari informasi buku C dan dokumentasi Surat Pemberitahuan Pajak Terutang. 

tambah kota Pontianak yang menyandang predika terbaik dalam pelayanan publik selama beberapa tahun berturut-turut.

Berdasarkan uraian di atas, akan dilakukan penelitian yang berjudul Pemanfaatan QGIS Untuk Pemetaan Fasilitas Layanan Masyarakat di Kota Pontianak. Sistem ini diharapkan dapat bermanfaat dan mempermudah masyarakat kota Pontianak menemukan lokasi fasilitas layanan publik yang ada di sekitarnya.

\section{LANDASAN TEORI}

\section{A. Sistem Informasi Geografis (SIG)}

Menurut Rhind dalam [3] Sistem Informasi Geografis (SIG) adalah sistem komputer yang ditujukan untuk pengumpulan, pemeriksaan, pemaduan dan analisis informasi yang berkaitan dengan permukaan bumi. Komponen dalam SIG terdiri dari 5 bagian yaitu people, procedure, data software SIG dan hardware SIG.

People dalam SIG adalah orang yang menjalankan, mengoperasikan, mengembangkan dan memperoleh manfaat dari sistem. Procedure SIG adalah kumpulan dari prosedur-prosedur yang digunakan untuk mengolah data menjadi informasi. Data dalam SIG terdiri dari dua yaitu data grafis dan data atribut. Software SIG merupakan program komputer yang dibuat khusus dan memiliki kemampuan pengelolaan, penyimpanan, pemrosesan, analisis dan penayangan data spasial. Hardware SIG berupa seperangkat komputer yang dapat mendukung pengoperasian perangkat lunak yang dipergunakan, contohnya adalah scanner, digitizer, PS, printer dan plotter.

\section{B. Quantum GIS (QGIS)}

Quantum GIS (QGIS) adalah perangkat lunak SIG berbasis open source dan free (gratis) untuk pengolahan data geospasial. QGIS lisensi di bawah GNU General Public License yang dapat diunduh pada https://www.qgis.org.

Langkah-langkah dalam pemetaan dengan QGIS adalah sebagai berikut :

1. Digitasi Peta

a. Digitasi tipe polygon: menambah objek (feature) polygon untuk kota atau kecamatan.

b. Digitasi tipe line: menambah objek (feature) line untuk jalan dan gang.

c. Digitasi tipe point : menambah objek titik (point) untuk lokasi-lokasi yang diamati

2. Georeferensi peta dasar: Proses georeferensi digunakan untuk menggambarkan posisi sebenarnya di muka bumi berdasarkan sistem koordinat nya. a. Proyeksi peta

Proyeksi peta merupakan cara untuk melakukan transformasi berbagai objek dari bentuk tiga dimensi permukaan bumi ke dalam tampilan dua dimensi.

b. Sistem Koordinat UTM

Dalam penggambaran dan pengukuran nya pada bidang datar, didasarkan pada 2 acuan yaitu geoid dan ellipsoid. Geoid merupakan suatu model permukaan bumi yang mendekati bentuk sesungguhnya. Ellipsoid adalah lingkaran elips tiga dimensional yang digunakan sebagai dasar referensi permukaan bumi dalam pembuatan peta [3].

Tampilan hasil digitasi tipe line pada QGIS dapat dilihat pada Gbr 1.

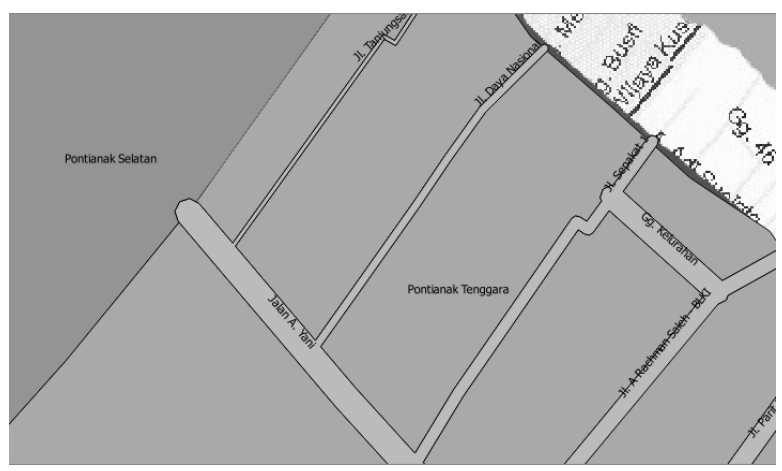

Gbr 1. Hasil Digitasi Tipe Line Pada QGIS

\section{QGIS $2 W E B$}

QGIS2WEB adalah sebuah plugin pada Quantum GIS yang berfungsi untuk membuat peta web dari project QGIS yang telah dibuat sebelumnya. Untuk menggunakan QGIS2WEB, terlebih dahulu install plugins QGIS2WEB yang terdapat di menu plugins pada QGIS. QGIS2WEB yang di install akan ditempatkan dalam menu web pada QGIS.

\section{Penelitian Terkait}

Abdulghani dan Ubaedilah [2] melakukan analisis dan perancangan SIG sebaran tanah penduduk di desa Tanjungsara Kabupaten Cianjur. SIG dibangun untuk memberikan kemudahan dalam administrasi pertanahan dengan berisi modul berupa pencatatan dan perubahan kepemilikan tanah dalam Buku C, riwayat tanah, penyesuaian dokumen didalam Buku $\mathrm{C}$ dengan surat pemberitahuan pajak terutang dan pemetaan tanah dengan menggunakan Google Maps API. Buku C merupakan buku khusus pencatatan kepemilikan tanah. Keuntuangan dibangunnya sistem ini adalah kemudahan bagi petugas kantor kepala desa dalam menambah, memperbaharui dan mencari informasi buku C dan dokumentasi Surat Pemberitahuan Pajak Terutang. 

burung berkicau di kota Malang mempermudah bagi para kicau mania dari kota Malang maupun luar kota Malang untuk mengetahui dimana lokasi penyebaran kontes burung khusunya di kota Malang. Dari pemetaan yang sudah dilakukan, diketahui bahwa wilayah kecamatan sukun paling banyak lokasi penyebaran dengan persentase penyebaran $35 \%$ dan kecamatan klojen menjadi lokasi penyebaran paling sedikit dengan persentase $5 \%$.

Kholil [5] melakukan penelitian dengan memanfaatkan SIG dalam aplikasi pelaporan dan pelacakan kejahatan berbasis Android. Pemetaan kejahatan dengan menggunakan Google Maps Android API yang merupakan bagian dari Google play services. Aplikasi yang dibangun memungkinkan terjadinya kesinambungan dan peran aktif masyarakat dalam mengatasi tindak kejahatan di lingkungan sekitar. Aplikasi ini tidak hanya fokus pada tindak kejahatan saja melainkan juga seperti pengaduan masyarakat berkaitan dengan unjuk rasa, kecelakaan, bahkan pungutan liar. Dengan aplikasi ini polisi juga bisa lebih awal mengetahui tindak kejahatan yang dilaporkan masyarakat secara realtime.

\section{METODOLOGI PENELITIAN}

Metodologi yang digunakan dalam penelitian ini adalah :

1. Studi literatur yang dilakukan adalah dengan membaca buku-buku yang berkaitan dengan teori-teori pendukung penelitian seperti teori tentang Sistem Informasi Geografis, terutama pemanfaatan aplikasi QGIS dalam melakukan pemetaaan wilayah. Mempelajari referensi dari jurnal ilmiah, tugas akhir yang berkaitan dengan penelitian dan berbagai sumber dari internet sebagai acuan untuk melakukan penelitian.

2. Pengumpulan data dilakukan untuk mendapatkan data yang akan digunakan pada penelitian ini. Peneliti melakukan survey lapangan pengumpulan data titik lokasi layanan masyarakat di kota Pontianak untuk dipetakan menggunakan aplikasi QGIS.

3. Pengolahan data yang dilakukan yaitu pemasukan data vektor yang dihasilkan dari survey lapangan berupa titik koordinat dan nama lokasi layanan masyarakat di kota Pontianak.

4. Implementasi yang dilakukan yaitu proses pemetaan fasilitas layanan masyarakat di kota Pontianak menggunakan aplikasi QGIS mulai dari georeferensi peta dasar, proses pembentukan layout, hingga membuat peta web hasil pemetaannya

5. Hasil dari penelitian ini yaitu berupa sebuah peta web yang dapat menampilkan pemetaan fasilitas layanan masyarakat di kota Pontianak yang dihasilkan dari aplikasi QGIS, dan dilakukan pembahasan mengenai lokasi layanan masyarakat berupa ATM, SPBU, Puskesmas, Rumah Sakit, PAUD, Bengkel yang terdapat di wilayah kota Pontianak.

\section{IV.RANCANGAN PENELITIAN}

\section{A. Kerangka Pemikiran}

Penelitian ini merupakan bentuk penelitian model eksperimen menggunakan alat bantu Tools QGIS. Tujuan penelitian ini adalah untuk melakukan pemetaan fasilitas layanan masyarakat di kota Pontianak. Data titik koordinat lokasi fasilitas layanan masyarakat yang telah dikumpulkan selanjutnya diolah ke dalam aplikasi QGIS untuk menghasilkan sebuah peta web. Kerangka pemikiran dalam penelitian ini dapat dilihat pada Gbr 2.

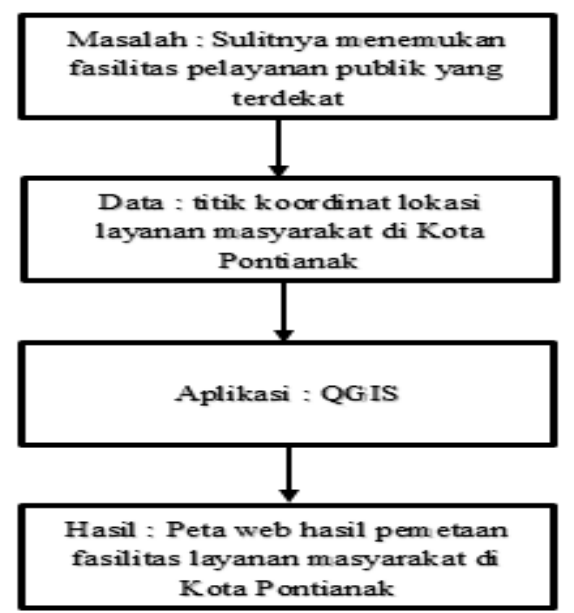

Gbr 2. Kerangka Pemikiran Penelitian

Penelitian ini dilakukan beberapa tahapan mulai dari pengumpulan data titik koordinat lokasi fasilitas layanan masyarakat, input data koordinat tersebut dalam aplikasi QGIS, pengolahan data koordinat dalam aplikasi QGIS, dan menghasilkan peta web pemetaan fasilitas layanan masyarakat di Kota Pontianak.

\section{B. Pengolahan Data}

Penelitian ini menggunakan peta dasar berupa peta Kota Pontianak yang diperoleh dari http://tanahair.indonesia.go.id/, serta titik koordinat Jalan-Gang sebanyak 7334 titik lokasi di seluruh Kota Pontianak. Terdapat 6 fasilitas layanan yang ada di kota Pontianak yang diolah dan dilakukan pemetaan menggunakan aplikasi QGIS. Fasilitas publik pertama yaitu Puskesmas sebanyak 24 lokasi yang titik koordinatnya dapat dilihat pada Tabel 1. 
TABEL I

TITIK KOORDINAT LOKASI PUSKESMAS

\begin{tabular}{|c|c|c|}
\hline wkt_geom & id & Puske \\
\hline $\begin{array}{l}\text { Point }(109.30660201125127173- \\
0.02491280642718818)\end{array}$ & 1 & $\begin{array}{l}\text { Puskesmas Pal } \\
\text { Tiga }\end{array}$ \\
\hline $\begin{array}{l}\text { Point (109.31454142918713046 - } \\
0.03995953696550566)\end{array}$ & 2 & $\begin{array}{l}\text { Puskesmas } \\
\text { Alianyang }\end{array}$ \\
\hline $\begin{array}{l}\text { Point (109.32060589273967821 - } \\
0.01362501781657792)\end{array}$ & 3 & $\begin{array}{l}\text { Puskesmas } \\
\text { Komyos Sudarso }\end{array}$ \\
\hline $\begin{array}{l}\text { Point (109.3103314164464166 } \\
0.00549415787792954)\end{array}$ & 4 & $\begin{array}{l}\text { Puskesmas } \\
\text { Khatulistiwa }\end{array}$ \\
\hline $\begin{array}{l}\text { Point (109.33421746282495235 - } \\
0.00924328527297595)\end{array}$ & 5 & $\begin{array}{l}\text { Puskesmas 24 Jam } \\
\text { Siantan Hilir }\end{array}$ \\
\hline $\begin{array}{l}\text { Point (109.34047839149995696 - } \\
0.01457895355264101)\end{array}$ & 6 & $\begin{array}{l}\text { Yayasan Rumah } \\
\text { Bersalin Nandaria }\end{array}$ \\
\hline $\begin{array}{l}\text { Point (109.36353279634997193 - } \\
0.00081377754646752)\end{array}$ & 7 & $\begin{array}{l}\text { Puskesmas Telaga } \\
\text { Biru }\end{array}$ \\
\hline $4929505-$ & 8 & $\begin{array}{l}\text { Puskesmas Siantan } \\
\text { Tengah }\end{array}$ \\
\hline $9544666-$ & 9 & $\begin{array}{l}\text { Puskesmas Siantan } \\
\text { Hulu }\end{array}$ \\
\hline $\begin{array}{l}\text { Point }(109.364 \\
0.0115414028\end{array}$ & 10 & $\begin{array}{l}\text { Puskesmas } \\
\text { Pembantu Gang } \\
\text { Wartawan }\end{array}$ \\
\hline $1903875-$ & 11 & $\begin{array}{l}\text { UPK } \\
\text { Purna }\end{array}$ \\
\hline $2294088-$ & 12 & UPTD Puskesmas \\
\hline $5371314-$ & 13 & $\begin{array}{l}\text { Pusk } \\
\text { H. H }\end{array}$ \\
\hline $7359654-$ & 14 & Puskesmas \\
\hline $19309681-$ & 15 & $\begin{array}{l}\text { Puskesmas Parit } \\
\text { Mayor }\end{array}$ \\
\hline $\begin{array}{l}\text { 21250192- } \\
6)\end{array}$ & 16 & $\begin{array}{l}\text { Puskesmas Karya } \\
\text { Mulia }\end{array}$ \\
\hline $40237923-$ & 17 & Puskesmas \\
\hline $6351951-$ & 18 & $\begin{array}{l}\text { Puskesmas Ban } \\
\text { Searasan }\end{array}$ \\
\hline $\begin{array}{l}\text { Point (109.35084191364258288 - } \\
0.0278937525180968)\end{array}$ & 19 & $\begin{array}{l}\text { Puskesmas } \\
\text { Kampung Dalam }\end{array}$ \\
\hline $\begin{array}{l}\text { 2) } \\
\text { 2) }\end{array}$ & 20 & $\begin{array}{l}\text { Puskesmas } \\
\text { Tanjung Hulu }\end{array}$ \\
\hline $\begin{array}{l}\text { Point }(109.3708951867695589- \\
0.02570639794791705)\end{array}$ & 21 & Klinik Anugrah \\
\hline $\begin{array}{l}\text { Point (109.37687824485858812 - } \\
0.02576316320492863)\end{array}$ & 22 & $\begin{array}{l}\text { Klinik Sehati } \\
\text { Medika }\end{array}$ \\
\hline $\begin{array}{l}\text { Point (109.37002397198085646 - } \\
0.02709505898404637)\end{array}$ & 23 & $\begin{array}{l}\text { Klinik Pesona } \\
\text { Bunda }\end{array}$ \\
\hline $\begin{array}{l}\text { Point (109.35233132645808496 - } \\
0.04858761681312079)\end{array}$ & 24 & $\begin{array}{l}\text { Klinik Pratama } \\
\text { Untan }\end{array}$ \\
\hline
\end{tabular}

Fasilitas publik kedua yaitu SPBU sebanyak 23 lokasi, yang titik koordinatnya dapat dilihat pada Tabel II.

TABEL II

TITIK KOORDINAT LOKASI SPBU

\begin{tabular}{|l|l|l|}
\hline \multicolumn{1}{|c|}{ wkt_geom } & id & \multicolumn{1}{c|}{ SPBU } \\
\hline $\begin{array}{l}\text { Point (109.29753593090455865 - } \\
0.02793910764617388)\end{array}$ & 1 & SPBU \\
\hline $\begin{array}{l}\text { Point (109.33179179325451003 - } \\
0.03420105544494013)\end{array}$ & 2 & SPBU \\
\hline $\begin{array}{l}\text { Point (109.33266961055943511 - } \\
0.02698790524757675)\end{array}$ & 3 & SPBU \\
\hline $\begin{array}{l}\text { Point (109.32014942774117117 - } \\
0.02808141480461792)\end{array}$ & 4 & SPBU \\
\hline $\begin{array}{l}\text { Point (109.31379904655206303 - } \\
0.01151825628466371)\end{array}$ & 5 & SPBU \\
\hline $\begin{array}{l}\text { Point (109.33207269479201784 - } \\
0.01783352478152084)\end{array}$ & 6 & SPBU \\
\hline
\end{tabular}

\begin{tabular}{|l|l|l|}
\hline \multicolumn{1}{|c|}{ wkt_geom } & id & SPBU \\
\hline $\begin{array}{l}\text { Point (109.29617675377676278 } \\
0.00918281408382971)\end{array}$ & 7 & $\begin{array}{l}\text { SPBU } \\
\text { Pertamina }\end{array}$ \\
\hline $\begin{array}{l}\text { Point (109.32046411060238711 } \\
0.00136108526167995)\end{array}$ & 8 & $\begin{array}{l}\text { SPBU } \\
\text { AKR }\end{array}$ \\
\hline $\begin{array}{l}\text { Point (109.33530464378945624 - } \\
0.01127114763938045)\end{array}$ & 9 & $\begin{array}{l}\text { SPBU } \\
\text { Pertamina }\end{array}$ \\
\hline $\begin{array}{l}\text { Point (109.35813544404390996- } \\
0.01615767910215174)\end{array}$ & 10 & $\begin{array}{l}\text { SPBU } \\
\text { Pertamina }\end{array}$ \\
\hline $\begin{array}{l}\text { Point (109.3638335059784481 - } \\
0.00543236901976142)\end{array}$ & 11 & $\begin{array}{l}\text { SPBU } \\
\text { Pertamina }\end{array}$ \\
\hline $\begin{array}{l}\text { Point (109.34845876240953544 } \\
0.00356193307305549)\end{array}$ & 12 & $\begin{array}{l}\text { SPBU } \\
\text { AKR }\end{array}$ \\
\hline $\begin{array}{l}\text { Point (109.36263343768578693 - } \\
0.05539212409427817)\end{array}$ & 13 & $\begin{array}{l}\text { SPBU } \\
\text { Pertamina }\end{array}$ \\
\hline $\begin{array}{l}\text { Point (109.35444367928273834- } \\
0.04659411818157433)\end{array}$ & 14 & $\begin{array}{l}\text { SPBU } \\
\text { Pertamina }\end{array}$ \\
\hline $\begin{array}{l}\text { Point (109.36893370463175756- } \\
0.04868962895650025)\end{array}$ & 15 & $\begin{array}{l}\text { SPBU } \\
\text { Pertamina }\end{array}$ \\
\hline $\begin{array}{l}\text { Point (109.31897923097770331 - } \\
0.04804559768634889)\end{array}$ & 16 & SPBU \\
\hline $\begin{array}{l}\text { Point (109.34517725381834907- } \\
0.03133682443067759)\end{array}$ & 17 & SPBU \\
\hline $\begin{array}{l}\text { Point (109.2940699508171889 - } \\
0.00740852750429035)\end{array}$ & 18 & SPBU \\
\hline $\begin{array}{l}\text { Point (109.31355497074196137- } \\
0.00612619647929643)\end{array}$ & 19 & SPBU \\
\hline $\begin{array}{l}\text { Point (109.34675772680654404- } \\
0.09267071735613863)\end{array}$ & 20 & SPBU \\
\hline $\begin{array}{l}\text { Point (109.33642353836164318 - } \\
0.04516552805148848)\end{array}$ & 21 & $\begin{array}{l}\text { SPBU } \\
\text { Pertamina }\end{array}$ \\
\hline $\begin{array}{l}\text { Point (109.36212684673645867 - } \\
0.02581992846194023)\end{array}$ & 22 & $\begin{array}{l}\text { SPBU } \\
\text { Pertamina }\end{array}$ \\
\hline $\begin{array}{l}\text { Point (109.35647849898145978 - } \\
0.06410668883032364)\end{array}$ & 23 & $\begin{array}{l}\text { SPBU } \\
\text { Pertamina }\end{array}$ \\
\hline
\end{tabular}

Fasilitas publik ketiga yaitu Rumah Sakit sebanyak 18 lokasi, yang titik koordinatnya dapat dilihat pada Tabel III.

TABEL III

TITIK KOORDINAT LOKASI RUMAH SAKIT

\begin{tabular}{|l|l|l|}
\hline \multicolumn{1}{|c|}{ wkt_geom } & id & RumahSakit \\
\hline $\begin{array}{l}\text { Point (109.32661919855141264 - } \\
0.02000147860146139)\end{array}$ & 1 & $\begin{array}{l}\text { Rumah Sakit } \\
\text { Antonius }\end{array}$ \\
\hline $\begin{array}{l}\text { Point (109.32519060712111525 - } \\
0.03099075215821374)\end{array}$ & 2 & Klinik Pratama \\
\hline $\begin{array}{l}\text { Point (109.30928455755511663 - } \\
0.04655069090106578)\end{array}$ & 3 & $\begin{array}{l}\text { Klinik Bersalin } \\
\text { Sakina }\end{array}$ \\
\hline $\begin{array}{l}\text { Point (109.33089172279933621 - } \\
0.03751177129641748)\end{array}$ & 4 & $\begin{array}{l}\text { Klinik Bersalin } \\
\text { Jeumpa }\end{array}$ \\
\hline $\begin{array}{l}\text { Point (109.30561734169727117 - } \\
0.03260633214542163)\end{array}$ & 5 & Klinik Prima \\
\hline $\begin{array}{l}\text { Point (109.32922505586743966 - } \\
0.01946243913923355)\end{array}$ & 6 & $\begin{array}{l}\text { Klinik Pratama } \\
\text { Pasificuseo }\end{array}$ \\
\hline $\begin{array}{l}\text { Point (109.29399301095568831 - } \\
0.00774193357078878)\end{array}$ & 7 & $\begin{array}{l}\text { Rumah Sakit } \\
\text { Umum Sultan } \\
\text { Abdurrahman } \\
\text { Alqadri }\end{array}$ \\
\hline $\begin{array}{l}\text { Point (109.28863607309875761 - } \\
0.03636356204865394)\end{array}$ & 8 & $\begin{array}{l}\text { Klinik Nada } \\
\text { Medika }\end{array}$ \\
\hline $\begin{array}{l}\text { Point (109.33375935563257997 - } \\
0.04089678072421726)\end{array}$ & 9 & $\begin{array}{l}\text { Rumah Sakit } \\
\text { Bhayangkara } \\
\text { Anton } \\
\text { Soedarwo }\end{array}$ \\
\hline $\begin{array}{l}\text { Point (109.35494310794325656- } \\
0.06144745486724246)\end{array}$ & $\begin{array}{l}\text { Rumah Sakit } \\
\text { Anugrah Bunda } \\
\text { Khatulistiwa }\end{array}$ \\
\hline $\begin{array}{l}\text { Point (109.36450096384312758 - } \\
0.06205472871635818)\end{array}$ & $\begin{array}{l}\text { RSUD Dr. } \\
\text { Soedarso }\end{array}$ \\
\hline
\end{tabular}




\begin{tabular}{|l|l|l|}
\hline \multicolumn{1}{|c|}{ wkt_geom } & id & RumahSakit \\
\hline $\begin{array}{l}\text { Point }(109.35699517800209435- \\
0.03624637278603829)\end{array}$ & 12 & $\begin{array}{l}\text { Rumah Sakit } \\
\text { Yarsi }\end{array}$ \\
\hline $\begin{array}{l}\text { Point }(109.33673421304214912- \\
0.03113234435272761)\end{array}$ & 13 & $\begin{array}{l}\text { Rumah Sakit } \\
\text { ProMedika }\end{array}$ \\
\hline $\begin{array}{l}\text { Point }(109.32719015149143615- \\
0.0281359541967002)\end{array}$ & 14 & $\begin{array}{l}\text { Rumah Sakit } \\
\text { Jiwa }\end{array}$ \\
\hline $\begin{array}{l}\text { Point }(109.34071163801773707- \\
0.03072177145202154)\end{array}$ & 15 & $\begin{array}{l}\text { Rumah Sakit } \\
\text { Kharitas Bakti }\end{array}$ \\
\hline $\begin{array}{l}\text { Point }(109.32957019127523779- \\
0.03774913375463816)\end{array}$ & 16 & $\begin{array}{l}\text { Rumah Sakit } \\
\text { Mitra Medika }\end{array}$ \\
\hline $\begin{array}{l}\text { Point }(109.35682020916873114- \\
0.07671235153267375)\end{array}$ & 17 & $\begin{array}{l}\text { Rumah Sakit } \\
\text { Bersalin } \\
\text { Nabasa }\end{array}$ \\
\hline $\begin{array}{l}\text { Point (109.35575704409836817 - } \\
0.06420863264467162)\end{array}$ & 18 & $\begin{array}{l}\text { Pontianak Eye } \\
\text { Center }\end{array}$ \\
\hline
\end{tabular}

Fasilitas publik keempat yaitu PAUD sebanyak 82 lokasi, yang sebagian titik koordinatnya dapat dilihat pada Tabel IV.

TABEL IV

TITIK KOORDINAT LOKASI PAUD/TK

\begin{tabular}{|l|l|l|}
\hline \multicolumn{1}{|c|}{ wkt_geom } & id & \multicolumn{1}{|c|}{ Paud / TK } \\
\hline $\begin{array}{l}\text { Point (109.30675589097427292 - } \\
0.02296366326919739)\end{array}$ & 1 & $\begin{array}{l}\text { TK Islam } \\
\text { "Harapan Indah" } \\
\text { Pontianak }\end{array}$ \\
\hline $\begin{array}{l}\text { Point (109.32382622822431983 - } \\
0.04209639509073287)\end{array}$ & 2 & TK Ikal \\
\hline $\begin{array}{l}\text { Point (109.32777891414608007 - } \\
0.03241532424169857)\end{array}$ & 3 & TK Islam Semesta \\
\hline $\begin{array}{l}\text { Point (109.32922355062510178 - } \\
0.03001762897442479)\end{array}$ & 4 & $\begin{array}{l}\text { TK dan Paud } \\
\text { Pertiwi }\end{array}$ \\
\hline $\begin{array}{l}\text { Point (109.32908309985630524 - } \\
0.02977685622792031)\end{array}$ & 5 & TK Bawamai \\
\hline $\begin{array}{l}\text { Point (109.32803975128813079 - } \\
0.02804128601353385)\end{array}$ & 6 & $\begin{array}{l}\text { TK Kemala } \\
\text { Bhayangkari XII }\end{array}$ \\
\hline $\begin{array}{l}\text { Point (109.32963487073371311 - } \\
0.02808141480461792)\end{array}$ & 7 & TK Cemerlang \\
\hline $\begin{array}{l}\text { Point (109.32731743304854888 - } \\
0.02174106581333324)\end{array}$ & 8 & $\begin{array}{l}\text { TK Aisyiyah } \\
\text { Bustanul Athfal 1 }\end{array}$ \\
\hline $\begin{array}{l}\text { Point (109.32364564866438172 - } \\
0.03173313479326922)\end{array}$ & 9 & TK Kartika XVII-1 \\
\hline $\begin{array}{l}\text { Point (109.32156898372578269 - } \\
0.03001762897442478)\end{array}$ & 10 & $\begin{array}{l}\text { TK Al- } \\
\text { Mukaddinah }\end{array}$ \\
\hline $\begin{array}{l}\text { Point (109.31628703159933025 - } \\
0.02954611567918684)\end{array}$ & 11 & Paud As-Sirath \\
\hline $\begin{array}{l}\text { Point (109.31682877027893142 - } \\
0.03745148752275065)\end{array}$ & 12 & $\begin{array}{l}\text { TK dan TAS } \\
\text { Lembaga } \\
\text { Kesejahteraan Ibu } \\
\text { dan Anak (LKIA) }\end{array}$ \\
\hline $\begin{array}{l}\text { Point (109.31616664522604765 - } \\
0.03841457850876857)\end{array}$ & 13 & $\begin{array}{l}\text { TK Islam Terpadu } \\
\text { Lebah Kecil }\end{array}$ \\
\hline $\begin{array}{l}\text { Point (109.31341782303678656 - } \\
0.04153459201555575)\end{array}$ & 14 & TK Go Smart \\
\hline $\begin{array}{l}\text { Point (109.30998681139911355 - } \\
0.04547724573956663)\end{array}$ & 15 & $\begin{array}{l}\text { TK Islam Al- } \\
\text { Adabiy }\end{array}$ \\
\hline $\begin{array}{l}\text { Point (109.31064893645199732 - } \\
0.04464457332457197)\end{array}$ & 16 & TK Gemilang \\
\hline $\begin{array}{l}\text { Point (109.31058874326537023 - } \\
0.04472483090674013)\end{array}$ & 17 & Paud PUS \\
\hline $\begin{array}{l}\text { Point (109.30972597425706283 - } \\
0.0497008010011661)\end{array}$ & 18 & $\begin{array}{l}\text { Paud Cerdas } \\
\text { Mandiri }\end{array}$ \\
\hline $\begin{array}{l}\text { Point (109.30775966349393968 - } \\
0.04850696946641471)\end{array}$ & 19 & Paud Kartini \\
\hline $\begin{array}{l}\text { Point (109.30766937371399194 - } \\
0.04843674408201757)\end{array}$ & 20 & TK Kartini \\
\hline $\begin{array}{l}\text { Point (109.30753895514297369 - } \\
0.04907880473936286)\end{array}$ & 21 & Paud Al-Hafidz \\
\hline $\begin{array}{l}\text { Point (109.30573210632778114 - } \\
0.05401796376337325)\end{array}$ & 22 & TAS Ceria \\
\hline
\end{tabular}

\begin{tabular}{|l|c|l|}
\hline \multicolumn{1}{|c|}{ wkt_geom } & id & \multicolumn{1}{|c|}{ Paud / TK } \\
\hline $\begin{array}{l}\text { Point (109.30194098878672548 - } \\
0.05666314625425405)\end{array}$ & 23 & $\begin{array}{l}\text { TKIT Yaa } \\
\text { Bunayya }\end{array}$ \\
\hline
\end{tabular}

Fasilitas publik kelima yaitu ATM sebanyak 257 lokasi, yang sebagian titik koordinatnya dapat dilihat pada Tabel V.

TABEL V

TITIK KOORDINAT LOKASI ATM

\begin{tabular}{|c|c|c|}
\hline wkt_geom & id & ATM \\
\hline $\begin{array}{l}\text { Point (109.30869862247713797 - } \\
0.01830880164846939)\end{array}$ & 1 & $\begin{array}{l}\text { ATM Bank } \\
\text { Kalbar }\end{array}$ \\
\hline $\begin{array}{l}\text { Point (109.32823036304577613 - } \\
0.02803125381576283)\end{array}$ & 2 & $\begin{array}{l}\text { ATM Bank } \\
\text { Kalbar }\end{array}$ \\
\hline $\begin{array}{l}\text { Point (109.33159114929905797 - } \\
0.0264160699746286)\end{array}$ & 3 & $\begin{array}{l}\text { ATM Bank } \\
\text { Mandiri }\end{array}$ \\
\hline $\begin{array}{l}\text { Point (109.33254922418618094 - } \\
0.02685748667655349)\end{array}$ & 4 & $\begin{array}{l}\text { ATM Bank } \\
\text { BRI }\end{array}$ \\
\hline $\begin{array}{l}\text { Point (109.33262948176835039 - } \\
0.02677722909438533)\end{array}$ & 5 & $\begin{array}{l}\text { ATM Bank } \\
\text { BCA }\end{array}$ \\
\hline $\begin{array}{l}\text { Point (109.33387347429194847 - } \\
0.02803125381576283)\end{array}$ & 6 & $\begin{array}{l}\text { ATM } \\
\text { Maybank }\end{array}$ \\
\hline $\begin{array}{l}\text { Point (109.33429482659833809- } \\
0.02840244513329057)\end{array}$ & 7 & $\begin{array}{l}\text { ATM Bank } \\
\text { Kalbar }\end{array}$ \\
\hline $\begin{array}{l}\text { Point (109.33439514857604991 - } \\
0.02831215535335139)\end{array}$ & 8 & $\begin{array}{l}\text { ATM Bank } \\
\text { BNI }\end{array}$ \\
\hline $\begin{array}{l}\text { Point (109.33613071879042877 - } \\
0.02998753238111173)\end{array}$ & 9 & $\begin{array}{l}\text { ATM Bank } \\
\text { Mandiri }\end{array}$ \\
\hline $\begin{array}{l}\text { Point (109.33621097637259822 - } \\
0.02989724260117255)\end{array}$ & 10 & $\begin{array}{l}\text { ATM Bank } \\
\text { Danamon }\end{array}$ \\
\hline $\begin{array}{l}\text { Point (109.34236071360625431 - } \\
0.02733903216956246)\end{array}$ & 11 & $\begin{array}{l}\text { ATM Bank } \\
\text { Kalbar }\end{array}$ \\
\hline $\begin{array}{l}\text { Point (109.34216006965083068 - } \\
0.02747948293835674)\end{array}$ & 12 & $\begin{array}{l}\text { ATM Bank } \\
\text { BRI }\end{array}$ \\
\hline $\begin{array}{l}\text { Point (109.33250909539511042 - } \\
0.03394021830289362)\end{array}$ & 13 & $\begin{array}{l}\text { ATM Bank } \\
\text { BNI }\end{array}$ \\
\hline $\begin{array}{l}\text { Point (109.34201961888203414 - } \\
0.02734906436733348)\end{array}$ & 14 & $\begin{array}{l}\text { ATM Bank } \\
\text { BNI }\end{array}$ \\
\hline $\begin{array}{l}\text { Point (109.34190926470655825 - } \\
0.02759986931160898)\end{array}$ & 15 & $\begin{array}{l}\text { ATM Bank } \\
\text { BCA }\end{array}$ \\
\hline $\begin{array}{l}\text { Point (109.33206767869319265 - } \\
0.03404054028060382)\end{array}$ & 16 & $\begin{array}{l}\text { ATM Bank } \\
\text { Permata Bank }\end{array}$ \\
\hline $\begin{array}{l}\text { Point (109.33564917329744048 - } \\
0.03081017259833537)\end{array}$ & 17 & $\begin{array}{l}\text { ATM Bank } \\
\text { BRI }\end{array}$ \\
\hline $\begin{array}{l}\text { Point (109.33612068659267891 - } \\
0.03034869150086845)\end{array}$ & 18 & $\begin{array}{l}\text { ATM Bank } \\
\text { BRI }\end{array}$ \\
\hline $\begin{array}{l}\text { Point (109.33238870902184203 - } \\
0.03404054028060381)\end{array}$ & 19 & $\begin{array}{l}\text { ATM Bank } \\
\text { Mandiri }\end{array}$ \\
\hline $\begin{array}{l}\text { Point (109.33603039681274538 - } \\
0.03042894908303661)\end{array}$ & 20 & $\begin{array}{l}\text { ATM Bank } \\
\text { Bukopin }\end{array}$ \\
\hline $\begin{array}{l}\text { Point (109.33992790564674635 - } \\
0.02315560569904706)\end{array}$ & 21 & $\begin{array}{l}\text { ATM Bank } \\
\text { BCA }\end{array}$ \\
\hline $\begin{array}{l}\text { Point (109.33979748707571389- } \\
0.02298505833693972)\end{array}$ & 22 & $\begin{array}{l}\text { ATM Bank } \\
\text { BNI }\end{array}$ \\
\hline $\begin{array}{l}\text { Point (109.33894475026518478 - } \\
0.02236306207513648)\end{array}$ & 23 & $\begin{array}{l}\text { ATM Bank } \\
\text { BRI }\end{array}$ \\
\hline $\begin{array}{l}\text { Point (109.34126218795029217 - } \\
0.02471059635355517)\end{array}$ & 24 & $\begin{array}{l}\text { ATM Bank } \\
\text { Mandiri }\end{array}$ \\
\hline $\begin{array}{l}\text { Point (109.34208482816751484 - } \\
0.0260248142615588)\end{array}$ & 25 & $\begin{array}{l}\text { ATM Bank } \\
\text { Danamon }\end{array}$ \\
\hline $\begin{array}{l}\text { Point (109.34223531113407546 - } \\
0.02625555481029226)\end{array}$ & 26 & $\begin{array}{l}\text { ATM Bank } \\
\text { Mandiri }\end{array}$ \\
\hline
\end{tabular}

Fasilitas publik keenam yaitu Bengkel sebanyak 467 lokasi, yang sebagian titik koordinatnya dapat dilihat pada Tabel VI.

TABEL VI

TITIK KOORDINAT LOKASI BENGKEL 


\begin{tabular}{|l|l|l|}
\hline \multicolumn{1}{|c|}{ wkt_geom } & Id & Bengkel \\
\hline $\begin{array}{l}\text { Point (109.30914102668076282 - } \\
0.0233227159561957)\end{array}$ & 1 & Bengkel \\
\hline $\begin{array}{l}\text { Point (109.310808057013233 - } \\
0.02269437375394866)\end{array}$ & 2 & Bengkel \\
\hline $\begin{array}{l}\text { Point (109.31180827521272647 - } \\
0.02284825347694793)\end{array}$ & 3 & Bengkel \\
\hline $\begin{array}{l}\text { Point (109.32017450823566662 - } \\
0.0376972763681406)\end{array}$ & 4 & Bengkel \\
\hline $\begin{array}{l}\text { Point (109.31938698071064664 - } \\
0.03670910488769513)\end{array}$ & 5 & Bengkel \\
\hline $\begin{array}{l}\text { Point (109.31892048351429025 - } \\
0.03631283307573984)\end{array}$ & 6 & Bengkel \\
\hline $\begin{array}{l}\text { Point (109.33155102050800167 - } \\
0.03378973533632831)\end{array}$ & 7 & Bengkel \\
\hline $\begin{array}{l}\text { Point (109.32865492739489355 - } \\
0.03482958236088665)\end{array}$ & 8 & Bengkel \\
\hline $\begin{array}{l}\text { Point (109.33622100857037651 - } \\
0.03006778996327989)\end{array}$ & 9 & Bengkel \\
\hline $\begin{array}{l}\text { Point (109.30286896708062727 - } \\
0.02060742746520798)\end{array}$ & 10 & Bengkel \\
\hline $\begin{array}{l}\text { Point (109.30344080235357751 - } \\
0.02034659032316145)\end{array}$ & 11 & Bengkel \\
\hline $\begin{array}{l}\text { Point (109.30588865860970316 - } \\
0.01927314516166231)\end{array}$ & 12 & Bengkel \\
\hline $\begin{array}{l}\text { Point (109.3054372097100071 - } \\
0.01949385351262475)\end{array}$ & 13 & Bengkel \\
\hline $\begin{array}{l}\text { Point (109.30861741640342188 - } \\
0.01813950681353704)\end{array}$ & 14 & Bengkel \\
\hline $\begin{array}{l}\text { Point (109.30880802816108144 - } \\
0.01677512791667832)\end{array}$ & 15 & Bengkel \\
\hline $\begin{array}{l}\text { Point (109.30885818914993024 - } \\
0.01563145737078203)\end{array}$ & 16 & Bengkel \\
\hline $\begin{array}{l}\text { Point (109.30895851112764205 - } \\
0.0137153075965172)\end{array}$ & 17 & Bengkel \\
\hline $\begin{array}{l}\text { Point (109.30917921947860805 - } \\
0.01320366551019517)\end{array}$ & 18 & Bengkel \\
\hline $\begin{array}{l}\text { Point (109.30904880090757558 - } \\
0.01284250639043845)\end{array}$ & 19 & Bengkel \\
\hline $\begin{array}{l}\text { Point (109.33496196775008968 - } \\
0.0193734671393725)\end{array}$ & 20 & Bengkel \\
\hline $\begin{array}{l}\text { Point (109.33599528412050006 - } \\
0.02021617175213819)\end{array}$ & 21 & Bengkel \\
\hline $\begin{array}{l}\text { Point (109.34195440959648238 - } \\
0.02555330096632085)\end{array}$ & 22 & Bengkel \\
\hline $\begin{array}{l}\text { Point (109.32630418107368087 - } \\
0.02003559219225983)\end{array}$ & 23 & Bengkel \\
\hline \begin{tabular}{l} 
Point (109.32618379470042669 - \\
\hline .0208936120056756$)$
\end{tabular} & 24 & Bengkel \\
\hline
\end{tabular}

\section{PEMBAHASAN}

\section{A. Proses Pemetaan Dengan QGIS}

Implementasi yang dilakukan yaitu proses pemetaan fasilitas layanan masyarakat di kota Pontianak menggunakan aplikasi QGIS versi 3.8. Langkah pertama yang dilakukan adalah membuat line jalan dan gang per kecamatan sekota Pontianak, lalu dilakukan buffer. Proses pembuatan line jalan dan gang ini dilakukan dengan menghubungkan titik koordinat 1 dan pada titik koordinat lainnya hingga terbentuk sebuah garis lurus antara titik pertama dan berikutnya. Jalan dan gang digabung menggunakan fitur intersection. Hasil layer jalan dan gang dapat dilihat pada Gbr 3 .

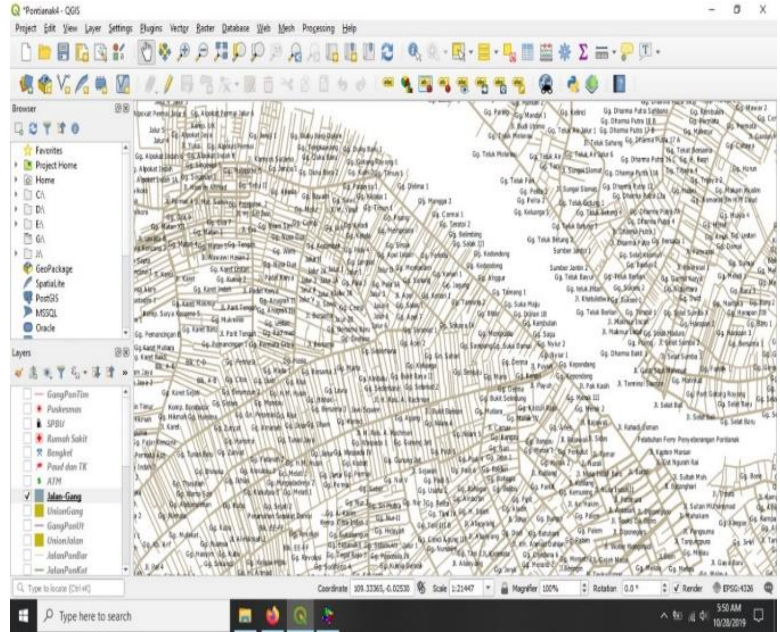

Gbr 3. Layer Jalan dan Gang

Pemberian nama, warna, histogram pada tiap koordinat dapat dilakukan dengan menggunakan layer properties yang dapat dilihat pada Gbr 4 .

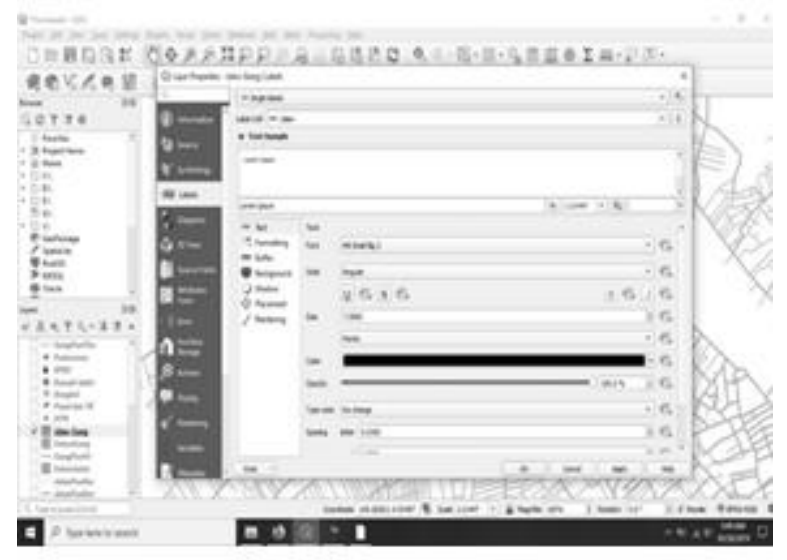

Gbr 4. Layer Properties

Langkah selanjutnya adalah pembuatan layer untuk setiap fasilitas masyarakat di Kota Pontianak. Salah satu layer yang dibuat adalah layer untuk fasilitas bengkel yang dapat dilihat pada Gbr 5 .

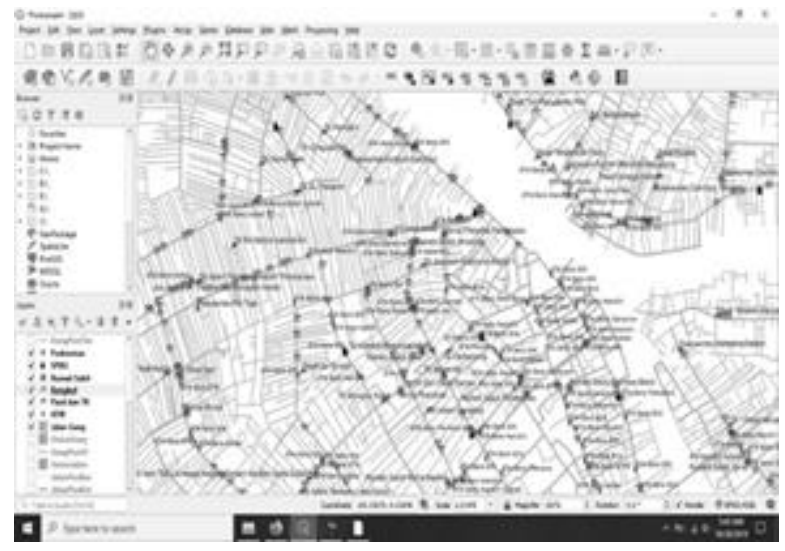




\section{Gbr 5. Layer Bengkel}

Setelah semua layer untuk setiap fasilitas publik telah dibuat, langkah berikutnya adalah mengatur tampilan untuk membuat peta web menggunakan plugin QGIS2WEB yang ada di aplikasi QGIS. Setelah

Page | 76 pengaturan tampilan selesai, langkah terakhir adalah melakukan export ke web map yang dapat dilihat pada Gbr 6.

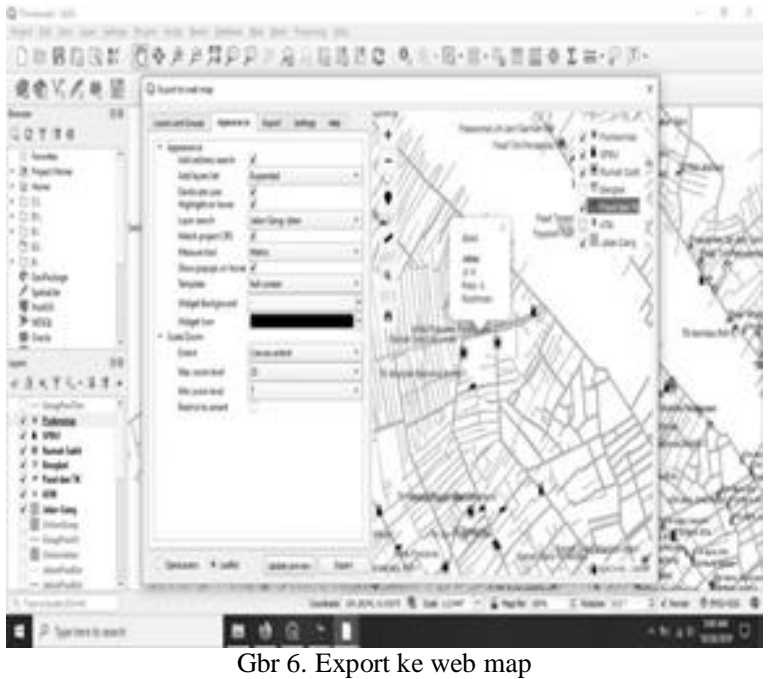

B. Peta Web Fasilitas Layanan Publik Kota Pontianak

Hasil proses export ke web map didapatkan sebuah peta web yang dapat menampilkan pemetaan fasilitas layanan masyarakat di kota Pontianak. Peta web tersebut dapat dilihat pada Gbr 7 .

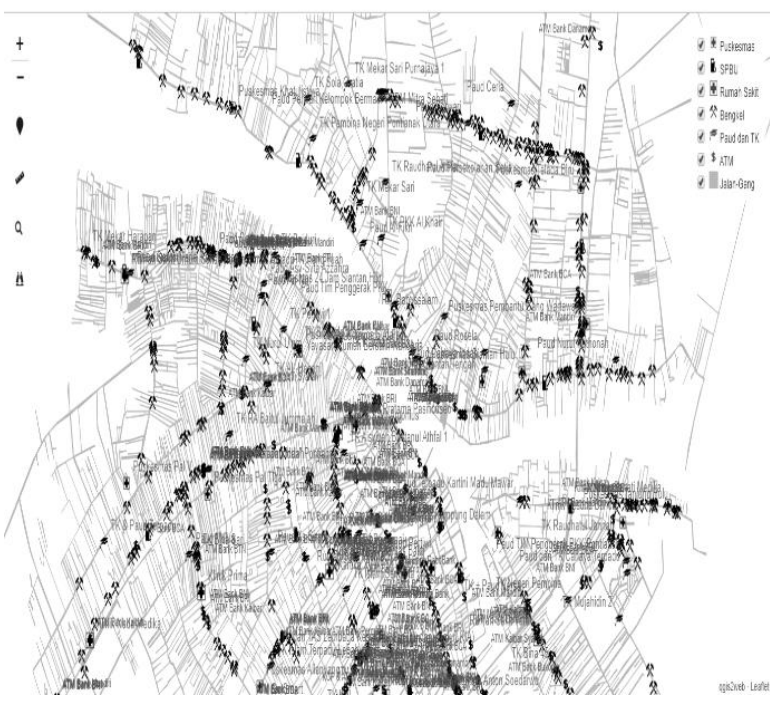

Gbr 7. Peta Web Fasilitas Pelayan Publik Kota Pontianak

Terdapat beberapa fitur yang dapat digunakan pada peta web tersebut, diantaranya seperti melakukan filter fasilitas layanan publik yang ingin ditampilkan, seperti pada Gbr 8 yang menunjukkan tampilan peta web khusus untuk fasilitas Puskesmas di Kota Pontianak.

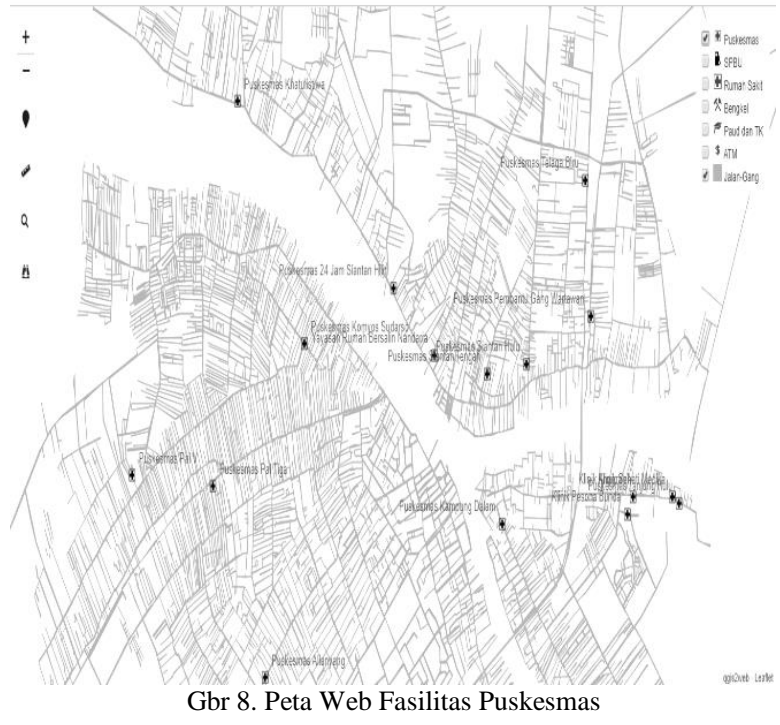

Selain itu, pada peta web tersebut juga dapat menampilkan lokasi pengguna, sehingga dapat dilihat fasilitas layanan publik yang ada di sekitar pengguna peta web tersebut, fitur ini dapat dilihat pada Gbr 9.

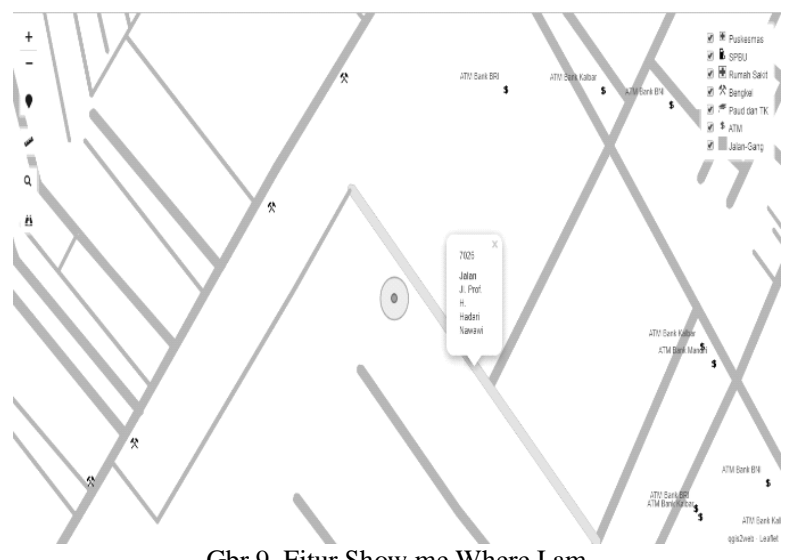

Gbr 9. Fitur Show me Where I am

Fitur berikutnya adalah menu pencarian lokasi jalan dari kata kunci nama jalan yang dimasukkan oleh pengguna peta web tersebut yang dapat dilihat pada Gbr 10 .

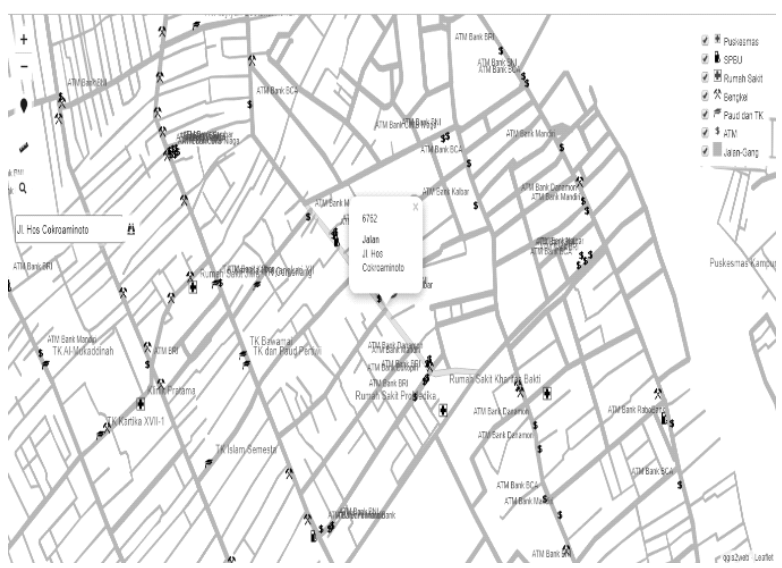

Gbr 10. Pencarian Lokasi Jalan 


\section{KESIMPULAN}

Kesimpulan yang dapat diambil dari penelitian ini yaitu:

1. Proses pengumpulan data titik lokasi layanan masyakarat di kota Pontianak dilakukan dengan

Page | 77 melakukan survey lapangan dan mencatat titik lokasi fasilitas layanan masyarakat untuk selanjutnya dimasukkan ke aplikasi QGIS.

2. Proses digitasi peta pada aplikasi QGIS dilakukan dengan pemasukan line jalan dan gang hingga point lokasi fasilitas layanan masyarakat.

3. Proses digitasi peta yang sudah selesai dilakukan proses export menjadi sebuah peta web yang ditampilkan menggunakan browser.

\section{REFERENSI}

[1] Pontianak, D.K., Jumlah Penduduk Kota Pontianak Semester II Tahun 2018 Capai 665.694 Jiwa. Available at: https://disdukcapil.pontianakkota.go.id/jumlah-penduduk-kotapontianak-semester-ii-tahun-2018-capai-665694-jiwa. 2019.

[2] Abdulghani, T. \& Ubaedilah, E., Analisis Dan Perancangan Sistem Informasi Geografis Sebaran Tanah Penduduk (Studi Kasus Desa Tanjungasari, Kab. Cianjur). Jurnal Produktif, 2, pp.1-12, 2018

[3] Budiyanto, E., Sistem Informasi Geografis dengan Quantum GIS Seno, ed., Yogyakarta: C.V Andi Offset, 2018.

[4] Nugroho, A. \& Kusuma, W.A., Sistem Informasi Geografis Pemetaan Lokasi Bird Contest Kota Malang Berbasis Android. Jurnal SISTEMASI, 7(September), pp.212-219, 2018.

[5] Kholil, Pemanfaatan Sistem Informasi Geografis (Sig) Dalam Aplikasi Pelaporan Dan Pelacakan Kejahatan Berbasis Android Jurnal Teknologi Informasi dan Komunikasi, 6(1), pp.51-58, 2017. 